\title{
IMPROVING LIFE SATISFACTION AND JOB SATISFACTION OF EMPLOYEES, THROUGH AN INTERVENTION TO THE SUPERVISORS
}

\author{
MEJORANDO LA SATISFACCIÓN VITAL Y LA SATISFACCIÓN LABORAL DE LOS \\ TRABAJADORES A TRAVÉS DE UNA INTERVENCIÓN PARA SUPERVISORES \\ DIRECTOS
}

\author{
Constanza Veloso-Besio* \\ Universidad de Tarapacá, \\ Arica - Chile. \\ Alejandro Cuadra-Peralta \\ Universidad de Tarapacá, \\ Arica - Chile. \\ Francisco Gil-Rodríguez \\ Universidad Complutense de Madrid, \\ Madrid - España. \\ Felipe Cuadra-Mira \\ Universidad de Valparaíso, \\ Valparaíso - Chile. \\ Felipe Ponce \\ Universidad de Tarapacá, \\ Arica - Chile. \\ Oscar Sjöberg \\ Universidad Arturo Prat, \\ Iquique - Chile.
}

\section{RESUMEN}

\begin{abstract}
El propósito de esta investigación fue analizar la efectividad de un programa de intervención, basado en psicología positiva y habilidades sociales, para mejorar la satisfacción vital y la satisfacción laboral de trabajadores pertenecientes a una organización del sector público. Para analizar la efectividad del programa de intervención se utilizó un diseño cuasi-experimental con un grupo control inactivo. La intervención se aplicó en una muestra de supervisores inmediatos de una organización pública del sector salud. Los grupos fueron conformados por la unidad de recursos humanos de la organización, atendiendo a las necesidades de ésta. El grupo experimental estuvo conformado por siete supervisores directos, mientras que el grupo control estuvo conformado por ocho supervisores. La efectividad del programa de intervención se evaluó tanto en los subordinados directos $(\mathrm{N}=41)$ de los supervisores que conformaron el grupo experimental, como en los subordinados de los supervisores pertenecientes al grupo control $(\mathrm{N}=36)$. El programa duró aproximadamente un mes y tres semanas. El análisis de datos evidenció
\end{abstract}

* Autor correspondiente / Corresponding author: cvelosob@academicos.uta.cl 
que el MANOVA Factorial 2X2 fue estadísticamente significativo. Asimismo, el efecto de interacción del ANOVA Univariado mostró un incremento estadísticamemte significativo en la satisfacción vital y en la satisfacción laboral de los subordinados de aquellos jefes que recibieron la intervención (grupo experimental), en comparación con los subordinados del grupo control. Adicionalmente, los tamaños del efecto encontrados fueron de magnitud media a alta, dependiendo del índice utilizado para su estimación. Nuestros hallazgos permiten afirmar provisionalmente que desplegar esfuerzos en la intevencion de los supervisores traerá beneficios para sus subordinados directos, tales como una mejor evaluación de la satisacción vital y la satisfacción laboral.

Palabras Clave: Habilidaddes Sociales, Psicología Positiva, Entreamiento, Intervención, Bienestar.

\begin{abstract}
The purpose of this research was to analyze the effectiveness of an intervention program to the supervisors, based on positive psychology and social skills, to improve life satisfaction and job satisfaction of their direct employees belonging to a public sector organization. To analyze the effectiveness of the intervention program, a quasi-experimental design with an inactive-control group was used. The intervention program was applied to a sample of immediate supervisors of a public organization of the health sector. Two groups were formed by the human resource unit: an experimental group of seven supervisors, and an inactive control group of eight supervisors. The effectiveness was evaluated in the direct subordinates $(\mathrm{N}=41)$ of the supervisors belonging to the experimental group, and in the subordinates $(\mathrm{N}=36)$ of the supervisors belonging to the control group. The intervention program lasted a total of one month and three weeks. Data analysis evidenced that the Factorial MANOVA 2 X2 was statistically significant. When performing univariate contrasts, ANOVA interaction effect showed a statistically significant increase in life satisfaction and job satisfaction of the subordinates of those supervisors who received the intervention (experimental group), relative to the subordinates of the control group. Additionally, the effect sizes were of medium to high magnitude, depending on the index used for its estimation. Deploying efforts in supervisors intervention will bring benefits for their direct subordinates, such as a better evaluation of life satisfaction and job satisfaction.
\end{abstract}

Key Words: Social Skills, Positive Psychology, Training, Intervention, Well-Being.

\section{INTRODUCTION}

The well-being of workers, and how to increase it, currently entice the attention of the scientific community (Bakker, Rodríguez-Muñoz, \& Derks, 2012; Le Blanc \& Oerlemans, 2016), due to its association with diverse outcome variables of interest to organizations (Luthans, Youssef, Sweetman, \& Harms, 2013; see Warr \& Nielsen, 2018).

While well-being as a positive psychological phenomenon is a promising field, efforts for the development of well-being have focused on fixing what is wrong, instead of developing what works well. A consequence of the above is that few workplaces have considering within its policies programs that promote the positive well-being of its employees (Page \& Vella-Brodrick, 2013).

In this context, it has been pointed out that organizations should invest in the positive well-being of their employees (Page \& Vella-Brodrick, 2013), paying special attention to the variables associated with general (life satisfaction) and labor well-being (job satisfaction) (Warr \& Nielsen, 2018) of the workforce. In this sense, well-being is not only valuable per se, but also because it has beneficial consequences (Diener \& Seligman, 2004), such as, less turnover intention and better performance (Erdogan, Bauer, Truxillo, \& Mansfield, 2012). It makes the study of workers' well-being important, as well as taking actions to improve it (Diener \& Seligman, 2004).

The increase of positive well-being of the worker, from the perspective of the development of what works well, has been addressed through interventions based on positive psychology (e.g., Le Blanc \& Oerlemans, 2016) and its related fields (positive organizational behavior, positive organizational scholarship), with favorable effects on life satisfaction and job satisfaction (e.g., Meyers \& van Woerkom, 2017; Meyers, van Woerkom, \& Bakker, 2013). However, the interventions have been applied and evaluated, to a large extent, to the employees themselves, leaving aside a significant organizational variable that affects workers, that is, the quality of the immediate supervisor's leadership.

Given the preceding, one way to address the well-being of the worker is through the intervention of the immediate supervisors, because at this level an effect of significant magnitude is achieved because the supervisors have more interactions with 
employees (Avolio, Reichard, Hannah, Walumbwa, \& Chan, 2009). In turn, organizations for different reasons cannot train all their staff, so they must make strategic decisions about who will receive training. In this line, the immediate supervisors should be within the priorities, since, in addition to supervising tasks, they should exercise functions associated with leadership. It should be noted that there are at least two types of leadership in organizations. A formal leadership, usually associated with supervisory positions; and a leadership that is not necessarily formal (Robbins \& Judge, 2017). In this investigation, reference will be made to the formal leadership of the supervisor

The aforesaid becomes relevant if one considers that, the well-being of the leaders not only provides a benefit for themselves but is also critical for the well-being of their employees (Roche, Luthans, \& Haar, 2014). That is why experts have begun to focus their interest on the relationship between the positivity of the leader and the well-being of their employees (Luthans et $a l ., 2013)$. In addition, within the key dependent variables of organizational behavior are the satisfaction of human capital and performance, variables that are directly influenced by the leader (Judge $\&$ Picolo, 2004), and with greater force by those who they occupy lower hierarchical levels, such as immediate supervisors (Avolio et al., 2009).

One way to approach the intervention of leaders (immediate supervisors) is through the contributions of positive psychology (PP) together with social skills training (Diener \& Oishi, 2005). PP focuses on the study of positive subjective experiences (e.g., positive emotions), positive indivual traits (e.g., wisdom), and civic virtues and positive institutions (Seligman \& Csikszentmihalyi, 2000, p. 5), as well as positive relationships (Park, Peterson, \& Sun, 2013). The focus of social skills in interpersonal relationships is a good complement to the PP and its related fields, as POS, because one of the pillars of PP are positive interpersonal relationships, which are considered fundamental for the well-being (Diener \& Oishi, 2005), and social skills provide the essential components to have (and improve) positive interpersonal relationships (Segrin \& Taylor, 2007).

Additionally, special emphasis was also placed on the transfer of learning (Ford, Baldwin, \& Prasad, 2018; Salas, Tannenbaum, Kraiger, \& Smith-Jentsch, 2012), that is, the skills learned during the sessions must be put into practice in the workplace with their subordinates. In simple terms, the program is provided to the immediate supervisors and then the effectiveness of the intervention is evaluated in their direct subordinates. It should be noted that, comparatively, there are few studies that follow this logic since it is common that the intervention to be applied and evaluated in those who receive it (e.g., Meyers et al., 2013).

Therefore, the general objective of this research was to analyze the effectiveness of an intervention program to the supervisors, based on positive psychology and social skills, to improve life satisfaction and job satisfaction of their direct employees belonging to a public sector organization.

\section{POSITIVE PSYCHOLOGY, SOCIALSKILLS,ANDINTERVENTIONS}

Positive psychology emerges as a response to the dramatic increase in attention devoted to the understanding and treatment of psychopathology and the biological and environmental factors (medical approach) that contributed to mental illness and problematic psychosocial functioning (Waterman, 2013). Consequently, this flourishing field has been intended to contribute to a more complete and balanced scientific understanding of human experience and convey valuable lessons about how to build a happy, healthy, productive and meaningful life (Park \& Peterson, 2009).

It should be mentioned that the medical approach has dominated the research carried out in the area of work and organizations, leaving aside the study and promotion of well-being in people (Bakker et al., 2012). This acquires special relevance if it is considered that the absence of discomfort/ damage/illness does not imply the attainment of well-being. In other words, well-being includes the lack of suffering, but it is much more than that (Seligman \& Csikszentmihalyi, 2000) since the elimination of negative states do not lead to encouraging positive states, that is, eliminating sadness does not lead to happiness (Diener, Lucas, \& Oishi, 2005). This has practical implications for those who work in the area of management of human resources, since, according to the above, the increase in the well-being of workers would involve a strategy quite different from those commonly used (e.g., stress reduction).

The focus at the end of the well-being continuum is the foundation behind the PP and its 
related fields, which are based on the premise that by changing our perspectives and understanding of ourselves and the others, growth and development will be promoted (Zander \& Zander, 2002). In the organizational area, this change and development will affect attitudes, work behaviors and performance (see Avey, Reichard, Luthans, \& Mhatre, 2011b; Meyers et al., 2013). This has led to consider the PP (and its fields) as a valid alternative to improve organizations today (Salanova, Llorens, Acosta, $\&$ Torrente, 2013).

One practical implication of PP is the so-called psychological interventions based on PP (Sin \& Lyubomirsky, 2009), which should be part of the policy and culture of organizations that value, promote and enhance health and well-being (Salanova, Llorens, \& Martínez, 2016), as is the case of Chile (Aguirre, 2018).

A psychological intervention based on PP considers, without pretending to be exhaustive, the application of interventions based on personal strengths, self-efficacy, optimism, hope, gratitude, savoring, and forgiveness. Each of them has efficacy studies (see Luthans \& Youssef, 2007; Lyubomirsky, Dickerhoof, Boehm, \& Sheldon, 2012; Meyers et al., 2013; Quinlan, Swain, \& Vella-Brodrick, 2012; Stone \& Parks, 2018). To maximize its effect, it has been suggested to apply these interventions in a combined way, instead of using them in isolation (Cameron, Mora, Leutscher, \& Calarco, 2011; Layous \& Lyubomirsky, 2014). PP-based interventions have provisionaly shown a favorable effect on the follower when applied to direct headship (e.g., Grant, Curtayne, \& Burton 2009). By intervening in intentional factors (e.g., using personal strengths, encouraging optimism), positivity is developed in the headship, which implies a more positive evaluation of the objective events of life. This positivity is instrumental because it helps to amplify the impact of positive events (Cameron et al., 2011), and to buffer the impact of negative ones (Luthans et al., 2013). In consequense, positivity has a pivotal role in facilitating favorable evaluations (Luthans et al., 2013), even when positivity does not develop directly in employees (Avey, Avolio, \& Luthans, 2011a), since the positivity of leaders affect how subordinates think, feel and behave (Peterson, Balthazard, Waldman, \&Thatcher, 2008).

Additionally, this kind of interventions can be supported by a methodology based on training (e.g., Page \& Vella-Brodrick, 2013), that is, an intervention based on positive psychology should be take into account the four components of an effective training, namely, information, demonstration, practice, and feedback (Salas \& Cannon-Bowers, 2001).

Social skills and their training, on the other hand, enjoy a long tradition, whose ultimate goal has been to improve the quality of life and we1l-being of people (Gil, Cantero, \& Antino, 2013). Social skills have been pointed out as indispensable resources for healthy organizations, organizational health, and workers'well-being (Moreno-Jiménez, Blanco-Donoso, Aguirre-Camacho, de Rivas, \& Herrero, 2014).

Within the social skills relevant to the context of work and organizations are assertiveness, make a criticism, make compliments, and change of behavior request, among others (e.g., CuadraPeralta, Veloso-Besio, Iribaren, \& Pinto, 2017; Gil, Rodriguez, \& Alcover, 1998; Moreno-Jiménez et al., 2014; Payne, 2005). As in the previous case, it has been recommended to focus on the training of more than one social skill to maximize its effect (Moreno-Jiménez et al., 2014). For example, assertive behaviors are perceived more positively when workers also show active listening, empathy and other social skills (Moreno-Jiménez et al., 2014). In this particular study, complimenting or criticizing in a socially appropriate manner is more likely to succeed when the person uses an assertive communication style.

The social skills training, in the field of work and organizations, have considered health professionals, paraprofessionals, management personnel (senior managers, middle managers, and direct supervisors) (Gil, 1998).

It should be mentioned that social skills, and their training, are considered an essential component in leadership development programs (Riggio \& Reichard 2008), especially at lower hierarchical levels, such as immediate supervisors (Mumford, Campion, \& Morgeson, 2007). Their importance is because they are considered one of the specific mechanisms that the leader uses to influence followers positively. Specifically, communication processes, as well as incentives, standards, compliments, etc. that leaders provide have an effect (positive) on their subordinates (Moreno-Jiménez et al., 2014). 
Studies have reported that having adequate social skills has been associated with higher life satisfaction (Segrin \& Taylor 2007), and when a leader exhibits them, to more significant job satisfaction of their subordinates (Cuadra-Peralta et al., 2017).

Finally, social skills training is articulated according to principles that are fundamental, such as, a) instructions and an explanation of the theoretical foundation; b) exposure to models; c) opportunity to practice manifest skills or behavioral rehearsal; d) reinforcement and feedback to molding behavioral practice; e) generalization of these perfected skills to the natural environment (Kelly, 2013). These principles were taken into account in this study since they are the mechanism by the social skills training is effective.

In attention to the exposed antecedents, the hypotheses to be contrasted were:

Intervention, based on PP and social skills, will statistically and significantly increase,

- H1: life satisfaction of the subordinates of the experimental group, in comparison with the subordinates of the control group.

- $\quad \mathrm{H} 2$ : job satisfaction of the experimental group's subordinates, in comparison with the subordinates of the control group.

Figure 1 represents the research model, which accounts for the established hypotheses and the reasoning that guided this study. For more details see Method section.

\section{METHOD}

\section{Participants}

A total of 15 first-level supervisors and 77 employees from the public sector, from the health area of the city of Arica (Chile), participated. The organization was going through a process of organizational change, which caused discomfort in several units. The experimental group consisted of the units that had generated the most resistance, as indicated by the human resources unit. The control group did not show problems.

The average age of the sample of supervisors was 41 years $(\mathrm{SD}=6.44)$, with an average of five years and two months in office. Thirty-three percent of them were men, and $67.3 \%$ were women. The supervisors were mainly physicians and nurses. Two groups were formed: an inactive control group of eight supervisors; an experimental group of seven supervisors to whom the intervention was applied.

The effectiveness of the intervention was registered in the subordinates $(n=41)$ of the supervisors of the experimental group, and in the subordinates $(\mathrm{n}=36)$ of the supervisors belonging to the control group. The subordinates were paramedical technicians, medical professionals, non-medical professionals, administrative staff (e.g., secretary). The average age of the subordinates of the experimental group was 35 years $(\mathrm{SD}=8.95) ; 87.8 \%$ were women. The average age

Figure 1. Research model.

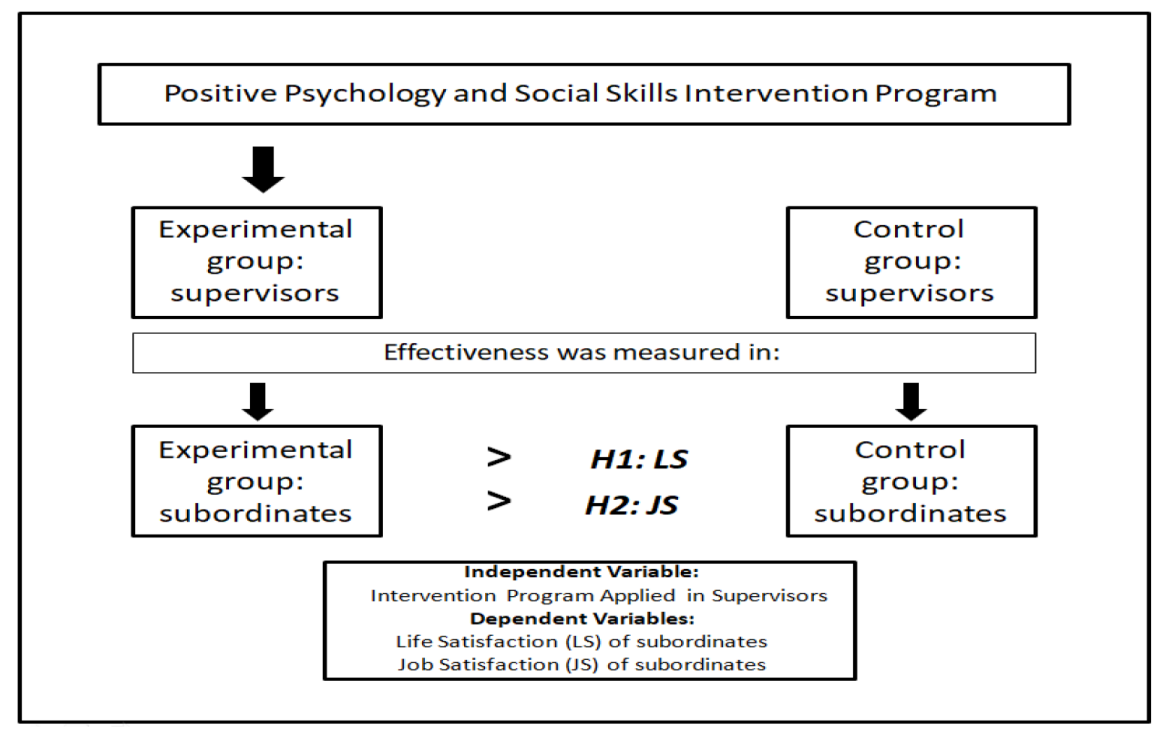


of the subordinates of the control group was 38 years $(\mathrm{SD}=9.34)$; $94.4 \%$ were women.

\section{Instruments}

Life satisfaction was measured through the Life Satisfaction Scale (Diener, Emmons, Larsen, \& Griffin, 1985). This scale measures how satisfied the person is with his/her life in general, relative to an ideal or desirable state (Diener et $a l ., 1985)$. It consists of five items presented on a seven-choice Likert scale, in which 1 means strongly disagree, and 7 means strongly agree. An example of an item is The conditions of my life are excellent. This scale has been widely used and has shown adequate psychometric properties through various studies (Erdogan et al., 2012).

In Chile, this scale was validated by Castro et al. (2012), who reported a Cronbach alpha of .87. Regarding the evidence of validity based on the internal structure, the confirmatory factor analysis evidenced a unifactorial structure, with appropriate global adjustment indicators. VeraVillarroel, Urzúa, Pavez \& Cellis-Atenas \& Silva (2012), also analyzed the psychometric quality of the scale, the results showed adequate indicators of internal consistency ( .82). In the factorial exploratory and confirmatory analysis was found a unifactorial solution.

Job satisfaction was measured through Overall Job Satisfaction Scale (Warr, Cook, \& Wall, 1979). This scale evaluates how satisfied a person is with different aspects of his/her job, such as recognition, co-workers, supervisor, salary, etc. Examples of items are: How satisfied are you with: your co-workers, your immediate supervisor, your salary. The total satisfaction with a job corresponds to the sum of all the items, forming a general measure of job satisfaction (Warr et al., 1979). It has 15 items presented in a response format ranging from 1 (very unsatisfied) to 5 (very satisfied). Its internal consistency reported was .88; and has unifactorial structure, with a first-order factor that explained $72 \%$ of the variance (Cuadra-Peralta \& Veloso-Besio, 2007).

Because the items of both instruments are in different response formats, a linear transformation of the original response formats to a percentage format (scale 0-100) was performed. The conversion of Likert responses to percentages facilitates the understanding of the results obtained between pre and posttest, that is, the magnitude of the change that occurred after manipulating the independent variable.

\section{Procedure}

Participants belonged to the public hospital in the city of Arica (Chile), which requested support to face an organizational change, determined at the national level. These changes were the result of the ministerial accreditation of the institution. This organization is the most important of those that belong to the health area and offers the highest coverage of health services for the population.

The assignment of the participants to the experimental conditions was made by the human resources unit of the organization, which assigned to the experimental group to those units that previously reported conflicts to the human resources unit. The control group did not show problems according to human resources unit. That is, we worked with natural groups, without random assignment. The intervention was considered within the formal courses of the organization. In this case, quasi-experiment is the best alternative to contrast the effectiveness of an intervention program whose purpose is to address a real situation (Grant \& Wall, 2009).

Each of the dependent variables (life satisfaction, job satisfaction) was recorded in the direct subordinates of the supervisors who belonged to the experimental group, and in the subordinates of the supervisors who belonged to the control group. Before applying the pretest measures, the participants signed an informed consent letter, in which the conditions of the study were explained: anonymity, voluntariness and a general explanation about the investigation. It should be reiterated that the organization requested support to carry out this intervention, for this reason, the study was not submitted to the ethics committee of the University, however it was approved by the psychology career committee.

The participation was totally anonymous. To ensure the anonymity of participation, each person of the experimental and the control group received an envelope containing the instruments. The participants should respond to the instruments in the workplace. Once the participants answered the questionnaires they should put them in the envelope and deposit them in a sealed box that the researchers provided. The box was available for one hour in a room arranged for that purpose. Within that hour, people entered the room and deposited 
Table 1.

\begin{tabular}{|c|c|c|c|}
\hline Session & Name of the session & Description & Activity/Task \\
\hline 1 & Presentation & $\begin{array}{l}\text { A formal presentation of the monitor is } \\
\text { performed. The objectives of the intervention } \\
\text { and a description of the working modality of } \\
\text { the workshops are presented. Subsequently, the } \\
\text { concepts of positive psychology and social } \\
\text { skills are explained. A brief review of the } \\
\text { scientific discoveries in positive psychology } \\
\text { and social skills is presented, and the benefits } \\
\text { of implementing them in organizations are } \\
\text { analyzed. }\end{array}$ & $\begin{array}{l}\text { As an activity, participants are asked to discuss } \\
\text { the potential benefits of positive psychology and } \\
\text { social skills in climate, job satisfaction, and life. } \\
\text { As well as the negative consequences of its lack } \\
\text { or inappropriate use. }\end{array}$ \\
\hline 2 & Leadership & $\begin{array}{l}\text { The meaning of leadership, its relevance, and } \\
\text { influence on variables of interest for } \\
\text { organizations are explained. Its structure is } \\
\text { described in the light of transactional and } \\
\text { transformational strategies. }\end{array}$ & $\begin{array}{l}\text { As a practical activity, the participants are asked } \\
\text { to remember throughout their lives, in their role } \\
\text { as subordinates, a good and a bad leader, and what } \\
\text { was the effect on variables such as climate, } \\
\text { performance, motivation, to name a few. They are } \\
\text { then asked to describe their leadership in the light } \\
\text { of transformational, transactional, and laissez- } \\
\text { faire styles. }\end{array}$ \\
\hline 3 & $\begin{array}{l}\text { Positive } \\
\text { interpersonal } \\
\text { relationships and } \\
\text { communication } \\
\text { styles }\end{array}$ & $\begin{array}{l}\text { The importance of establishing and } \\
\text { maintaining healthy interpersonal relationships } \\
\text { through a positive approach was explained and } \\
\text { taught to recognize the consequences of } \\
\text { negative interpersonal relationships } \\
\text { The behavioral, cognitive differences of } \\
\text { inhibited, aggressive, and assertive } \\
\text { communication styles, as well as their } \\
\text { consequences, were explained. }\end{array}$ & $\begin{array}{l}\text { The practical activity in the session consisted of } \\
\text { identifying a situation in which the person has } \\
\text { experienced a positive interpersonal relationship } \\
\text { and a negative one. Following they had to answer: } \\
\text { what they felt, what they thought, how they } \\
\text { reacted to it. }\end{array}$ \\
\hline 4 & $\begin{array}{l}\text { Making and } \\
\text { receiving } \\
\text { compliments }\end{array}$ & $\begin{array}{l}\text { The advantages of expressing compliments in } \\
\text { the creation of positive relational spaces within } \\
\text { the unit of work are explained. It is explained } \\
\text { how the proper and specific use of compliment } \\
\text { increases the motivation and the probability } \\
\text { that a subordinate performs more positive } \\
\text { behaviors for the work unit. } \\
\text { The steps to optimally implement compliments } \\
\text { for the staff are described. It describes how to } \\
\text { accept a compliment in a socially acceptable } \\
\text { manner. }\end{array}$ & $\begin{array}{l}\text { During the session, participants should perform a } \\
\text { round of compliments and describe how they felt } \\
\text { and extrapolate to their workers. It was left as a } \\
\text { task to praise the workers (for work well done) } \\
\text { and to record the activity in the log. }\end{array}$ \\
\hline 5 & $\begin{array}{l}\text { Happiness and life } \\
\text { satisfaction }\end{array}$ & $\begin{array}{l}\text { The consequences of assessing the positive } \\
\text { things that happen every day are explained to } \\
\text { the participants, emphasizing that they should } \\
\text { not be extraordinary, but rather simple and } \\
\text { daily, since they are also essential and } \\
\text { influence favorably. }\end{array}$ & $\begin{array}{l}\text { The task for the home consisted of making a } \\
\text { diary, in which the participant had to write, three } \\
\text { good things that would have happened during the } \\
\text { week. } \\
\text { VIA Questionnaire application. }\end{array}$ \\
\hline 6 & Tasting/ savoring & $\begin{array}{l}\text { Participants are introduced to the concept of } \\
\text { savoring and the importance of taking time } \\
\text { during the day to perform simple and enjoyable } \\
\text { activities, as well as ways to do so. }\end{array}$ & $\begin{array}{l}\text { The task consisted of planning and carrying out } \\
\text { activities that produce pleasure, and then } \\
\text { recording the experience in the log. }\end{array}$ \\
\hline 7 & Gratitude & $\begin{array}{l}\text { It is explained what gratitude is. Its effects and } \\
\text { its importance in organizations. }\end{array}$ & $\begin{array}{l}\text { The task was to choose a person who has } \\
\text { something to thank and has never been done } \\
\text { correctly, writing a thank-you letter that should be } \\
\text { read in person. }\end{array}$ \\
\hline 8 & $\begin{array}{l}\text { Personal strengths } \\
\text { and confidence }\end{array}$ & $\begin{array}{l}\text { The results of the VIA Questionnaire are } \\
\text { delivered. The concepts of strengths and } \\
\text { virtues are explained. The effects of the use of } \\
\text { the strengths are mentioned. It discloses the } \\
\text { classification of strengths and virtues. } \\
\text { The concept of trust and the differences } \\
\text { between resilient trust and naive trust are } \\
\text { defined. The ways to develop it are explained. }\end{array}$ & $\begin{array}{l}\text { The activity of the session is to identify the } \\
\text { strengths that are used more frequently in } \\
\text { different contexts. } \\
\text { The task for the household consisted of using the } \\
\text { three most distinctive strengths (according to the } \\
\text { VIA inventory). } \\
\text { The activity for the trust module consisted of } \\
\text { reflecting on how trust can affect the success or } \\
\text { failure of real personal experiences. }\end{array}$ \\
\hline 9 & $\begin{array}{l}\text { Optimism } \\
\text { hope }\end{array}$ & $\begin{array}{l}\text { The differences between the optimistic and } \\
\text { pessimistic explanatory styles and the } \\
\text { advantages of being optimistic are explained. } \\
\text { The personal explanatory style used in the face } \\
\text { of successes and failures is identified and } \\
\text { analyzed. } \\
\text { The effects of hope in different domains are } \\
\text { explained and how to develop hope is taught. }\end{array}$ & $\begin{array}{l}\text { The activity consisted in identifying, during the } \\
\text { session, three opportunities that were lost and } \\
\text { then three opportunities that have been won, } \\
\text { paying special attention to those thoughts that led } \\
\text { them to persevere and those that led them to } \\
\text { retreat. } \\
\text { The activity in the session consisted of applying } \\
\text { the techniques to develop hope. }\end{array}$ \\
\hline 10 & $\begin{array}{l}\text { Critical expression } \\
\text { and request for } \\
\text { behavior change }\end{array}$ & $\begin{array}{l}\text { The differences between assertive criticism and } \\
\text { inadequate criticism and its consequences on } \\
\text { the work environment are explained to the } \\
\text { participants. They are taught to carry out } \\
\text { socially appropriate criticisms. The } \\
\text { consequences of direct and indirect criticism } \\
\text { are analyzed. The essential elements of a } \\
\text { request for appropriate behavior change and its } \\
\text { effects are presented. }\end{array}$ & $\begin{array}{l}\text { During the session, the participants analyzed the } \\
\text { consequences of three different situations: } \\
\text { indiret criticism, direct criticism, direct positive } \\
\text { comments. } \\
\text { The second activity was to represent, and then } \\
\text { analyze, an inadequate criticism, and then the } \\
\text { same situation but in the light of a socially } \\
\text { appropriate criticism. } \\
\text { Participants shared the way they ask their work } \\
\text { colleagues/subordinates for behavioral changes, } \\
\text { analyzing the negative and positive aspects of } \\
\text { their actions. }\end{array}$ \\
\hline 11 & Forgiveness & $\begin{array}{l}\text { It is revealed that forgiveness is used as a tool } \\
\text { capable of modifying negative feelings. The } \\
\text { importance of forgiveness in the organizational } \\
\text { context is defined. The REACE technique is } \\
\text { explained. }\end{array}$ & $\begin{array}{l}\text { There were two activities during the session. The } \\
\text { first activity in which the participants had to apply } \\
\text { the REACE technique. The second activity, a } \\
\text { group activity, was to analyze irrational thoughts } \\
\text { that hinder forgiveness and analyze their effects } \\
\text { in the workplace. }\end{array}$ \\
\hline 12 & Clousure & $\begin{array}{l}\text { The changes are discussed with the participants } \\
\text { at a personal level and in the work } \\
\text { environment. It is highlighted that the stability } \\
\text { of the changes depends on the continuity of the } \\
\text { implementation of the strategies learned during } \\
\text { the training. }\end{array}$ & \\
\hline
\end{tabular}


the envelopes. This procedure was carried out for both pre and posttest in both groups.

The sessions were held in the workplace, during working hours. The training methods applied were: lectures, discussion groups, role-playing and cognitive-behavioral techniques (instructions, modeling, behavioral rehearsal, feedback, reinforcement and generalization strategies).

A manual based on PP and social skills was designed, which contained each of the topics to be held in the sessions, along with the corresponding logs for the tasks to be developed outside the sessions that supervisors of the experimental group had to carry out.

The total duration of the intervention was one month and three weeks approximately. Twelve sessions were applied, which consisted of one presentation session, one of closure, and ten sessions corresponding to the application of the workshops. The 10 sessions consisted of transformational and transactional leadership; make and receive compliments; personal strengths and self-efficacy; expression of criticism and request for change of behavior; positive interpersonal relationships; happiness and satisfaction; optimism and hope; gratitude; savoring; forgiveness. A more detailed description of the contents and activities of each session are presented in Table 1.

The ten sessions were applied twice a week, on different days. The duration of each session was approximate of 60 to 90 minutes. The reason for using this time-spaced modality is to allow participants to put into practice, in their workplace, the skills acquired in the training, making feedback and corrections on how these skills are being applied at the workplace (after modeling behaviors in the sessions), that is, through the intervention spaced out over time we can facilitate the transfer of learning and favor its feedback (Veloso-Besio, Gil-Rodríguez, González-Acuña, Cuadra-Peralta, \& Valenzuela-Carrera, 2018).

During the sessions, the supervisors of the experimental group had to carry out the activities and register them in the logbooks provided, with the objective to maximize the transfer probabilities (Ford et al., 2018). Then, the logbooks were fed back by the trainer and then were commented (with the consent of the participants) at the beginning of the next session.
It should be reiterated that the intervention was applied to the supervisors and the effectiveness was recorded in their respective subordinates. The pretest records were taken one week before the intervention began. Two/three weeks after the last session concluded, the post-measurement of the dependent variables was applied in both groups of subordinates, so the participants could put into practice the contents reviewed in the last session (forgiveness). In this sense, facilitating the conditions for an appropriate transfer is an aspect directly linked to the success of the training (Salas \& Cannon-Bowers, 2001). It should be mentioned that in real work environments, not all workers are available to respond to the instruments at the same time, due to this an additional week was granted (week three). With that, the vast majority of posttest records for the experimental group and the control were taken.

\section{Data analysis}

The analytical strategy was as follows. First, a t-test for independent samples was performed to check the initial equivalence (pretest) of the experimental and control groups, on each of the dependent variables: life satisfaction and job satisfaction.

Once the initial differences in the pretest were ruled out (non-random selection bias of the groups) a Factorial MANOVA 2X2 (Group $\mathrm{X}$ Evaluation Time) was carried out to control the Type I error, due to the use of more than one dependent variable. It should be added that the multivariate significance test chosen to contrast the interaction effect was the Pillai trace. Although the different multivariate tests (Wilks' Lambda, Hotelling's trace, Roy's largest root) tend to provide comparable results, the consensus is that the Pillai trace is the most robust in the violations of the assumptions, therefore it is recommended to use it routinely (Gardner, 2003).

Because the MANOVA Factorial was statistically significant a Factorial ANOVA for each of the dependent variables was performed. Finally, different measures of effect size (eta square, standardized mean differences, Morris standardized mean difference) were estimated to quantify the magnitude of the change observed in both dependent variables. 


\section{RESULTS}

Before performing the data analysis, it was examined whether the experimental and control group were comparable to each other. A t-test was applied for independent samples on each dependent variable considering only the pretest records. No statistically significant differences were found before the intervention between both groups in job satisfaction $[t(75)=0.596, p=.553]$, nor life satisfaction $[t(75)=-1.058, p=.294]$.

Notwithstanding, given that one of the dependent variables (life satisfaction) did not fully meet the normality requirements, the non-parametric U Mann-Whitney-test was applied which showed that there were no statistically significant differences in the pretest between the experimental group and control [Mann-Whitney $U p=.257$ ].

Table 2.

\begin{tabular}{clcccccccc}
\hline DVS & Conditions & $N$ & Mean & $S D$ & $F$ & $p$ & $\eta^{2}$ & $d$ & $d p p c$ \\
\hline \multirow{3}{*}{ Life } & Ctrlpre & 36 & 70.99 & 24.13 & & & & & \\
Satisfaction & Ctrlpost & 30 & 53.09 & 17.32 & 20.806 & .000 & 0.104 & 0.68 & 1.33 \\
\cline { 2 - 9 } & Exppre & 41 & 76.47 & 21.37 & & & & & \\
& Exppost & 40 & 88.88 & 15.83 & & & & & \\
\hline \multirow{3}{*}{ Job } & Ctrlpre & 36 & 66.90 & 18.39 & & & & & \\
Satisfaction & Ctrlpost & 30 & 60.56 & 13.84 & 10.633 & .001 & 0.066 & 0.53 & 1.03 \\
\cline { 2 - 8 } & Exppre & 41 & 64.55 & 16.17 & & & & & \\
& Exppost & 40 & 76.08 & 16.81 & & & & & \\
\hline
\end{tabular}

Note: $\eta^{2}=$ eta square, $d=$ standardized mean difference calculated from $\eta^{2} ; d p p c=$ effect size according to Morris (2008)

To analyze the effectiveness of the intervention a factorial MANOVA 2X2 (Group X Evaluation Time) was performed. We focus only on the interaction effect. The interaction effect analyzes the combined effect of the factors Group (experimental-control) and Evaluation Time (prepost) on the dependent variables, providing more information about the effect of the intervention than main effects.

The interaction effect of MANOVA showed that the interaction of the independent variables Evaluation Time and Group on the set of dependent variables was statistically significant [Pillai's trace $=0.142, F(2,142)=11.778, p=.000]$.

Due to a statistically significant multivariate effect was observed, univariate factorial ANOVA tests were performed for each dependent variable, that is, it was analyzed the interaction effect for each dependent variable individually. The results of factorial ANOVA showed a statistically significant interaction of the independent variables on life satisfaction $[F(1,143)=20.806, p=.000]$ and job satisfaction $[F(1,143)=10.633, p=.001]$ (Table 2).
The interaction effect can be easily understood using a graphic representation. For reasons of space, only the variable life satisfaction will be explained (Figure 1). This explanation can be extended to job satisfaction variable (Figure

\section{Figure 1.}

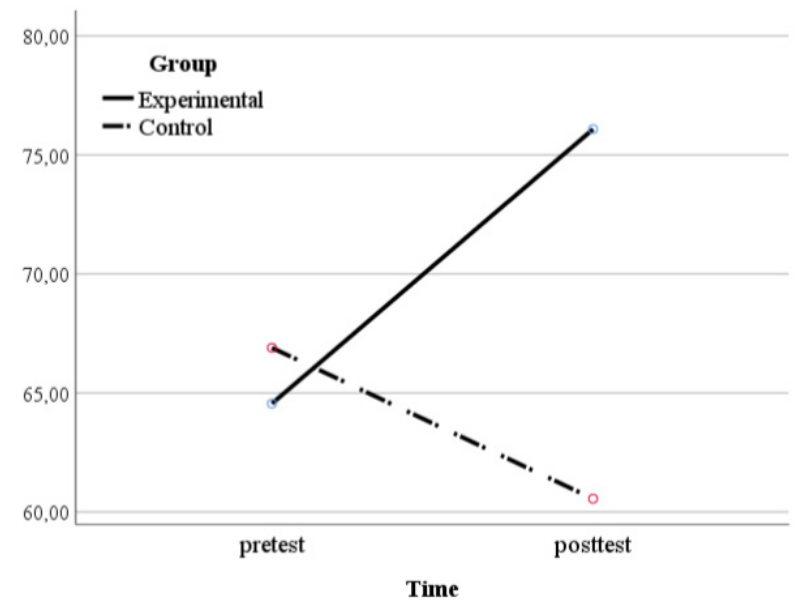


Figure 2.

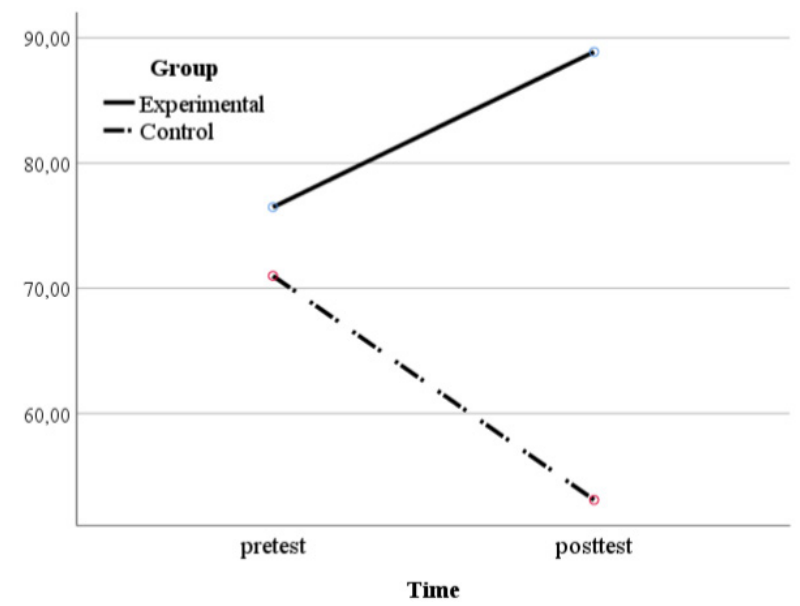

2). As mentioned above, the $F$ of the interaction effect (factorial ANOVA) for life satisfaction was statistically significant. In Figure 1, the slope of the experimental group (solid line) reveals an increase in life satisfaction between the pre and posttest. On the contrary, the slope of the control group (segmented line) shows a decrease in the life satisfaction between pre and posttest (this decrease will be explained in the Discussion section). The difference in the direction of the slopes was statistically different from zero.

Due to significance tests cannot determine the magnitude of a difference it is useful to calculate some measure of the effect size that indicates whether the difference is small or large. In consequence, three measures of effect size were estimated (in Table 2). Two of them, eta square $\left(\eta^{2}\right)$ and their equivalence in standardized mean difference $(d)$, are the effect sizes measures usually reported in the publications. The Cohen's $d$ was obtained from the conversion of the $\eta^{2}$ into $d$, using the spreadsheet elaborated by DeCoster (2012), which was based on the formulas contributed by Cohen (1988) to carry out the transformation. The $d$ (and $d$ ppc below) value represents the magnitude of the difference between the means of two groups (e.g., experimental versus control), that is, how much change occurred because of the intervention.

Although the $\eta^{2}$ of the interaction effect is a measure of the effect size used by the researchers, a problem observed was that the $\eta^{2}$ of the interaction effect does not consider the direction of the change. This situation is not a major problem when the control group does not show variations between the pre and posttest, but it does constitute a limitation in the estimation of the magnitude of the effect when the control group presents statistically significant variations. In this case, the $\eta^{2}$ of the interaction effect provides a lower estimate of the magnitude of the change.

Due to the above we use a third measure of effect size, the $d$ of Morris (2008), $d$ ppc, which does consider in its formula the direction of the change, being the most appropriate alternative in this type situations (decrease of the control group).

The $d$ and $d \mathrm{ppc}$ interpretation were done under the suggested classification by Cohen (1988), in which absolute values of the $d$ (and $d \mathrm{ppc}$ ) of $0.20,0.50$ and 0.80 correspond to effect sizes low, medium and high size respectively.

The effect sizes obtained by $d$ were of moderate magnitude (0.54-0.76), while the effect sizes obtained by $d \mathrm{ppc}$ were of a high magnitude (1.03-1.33) (see Table 2).

\section{DISCUSSION}

The objective of this research was to analyze the effectiveness of an intervention program to the supervisors, based on positive psychology and social skills, to improve life satisfaction and job satisfaction of their direct employees belonging to a public sector organization. It is important to recall that the intervention was applied in the supervisors, but the effectiveness was evaluated in the workers, who were subordinated to these supervisors.

The results show that the workers whose supervisors received the intervention achieved changes in life satisfaction and job satisfaction in relation to those workers whose direct supervisors 
did not receive the intervention. The magnitude of the change, estimated according to Morris (2008), can be classified as large.

It is important to remark that a statistically significant improvement was achieved in one of the two key output variables studied in organizational behavior, that is, job satisfaction (the other is performance), which is mentioned in compulsory reading manuals in any organizational psychology course, such as Robbins \& Judge (2017). In addition, these results were achieved with a fairly low cost, since only the immediate supervisors were required to train, but its effect was felt by the workers under their supervision.

Through the sessions that considered components associated with PP and social skills, supported by a training methodology, personal and social resources were developed in the supervisors. Regarding the PP, intentional factors were intervened (e.g., individual strengths, optimism), this implies the modification of the attitude towards ourselves, the others and the world that surrounds us (Zander \& Zander, 2002), that is to say, develop positivity in supervisors. This positivity is instrumental because it helps to amplify the impact of positive events (Cameron et al., 2011), but also to buffer negatives, affecting attitudes and behaviors of their direct employees (Luthans et al., 2013). In this sense, as pointed out by Roche et al. (2014), the well-being of leaders is essential for the well-being of their workers.

In turn, social skills training contributed to change specific behaviors profoundly linked to the workplace context (such as recognizing work well done, requesting behavior changes, etc.). In this sense, recognition (social) for work well done, from the part of an immediate supervisor, has an effect on the worker's job satisfaction. Therefore, both the PP and social skills provide tools that help create healthy relational spaces, which then affect positively the well-being (personal and labor) of the worker.

A not contemplated result was the decrease in life satisfaction and job satisfaction in the subordinates of the control group, as can be seen in Figures 1 and 2. It is possible that this decrease was due to the changes that the organization was going through, as a consequence of organizational restructuring due to ministerial accreditation. This process was developed transversally in all the units of the organization and their respective levels so that both the control and experimental groups were subject to the same circumstances. This could be evidence that the intervention, based on PP and social skills, not only improves the functioning of these variables but also counteracts the impact of organizational changes and overcomes resistance to change (Cameron et al., 2011; Grant et al., 2009).

Another possible explanation can be attributed to the effect of the social comparison that the subjects of the control group may have experienced, who, in addition to being affected by the organizational restructuring, did not benefit from the intervention, a situation that could affect both the perception of the organization as aspects of their life. Specifically, the subjects of the control group may have observed that the subjects of the experimental group were treated better by their supervisors (who received training) than those of the control group (their supervisors did not receive the intervention), affecting their judgments of life satisfaction and job satisfaction.

A first limitation is that the sample consisted only of a public sector organization from the health area, so it is recommended being careful when generalizing the findings to other populations.

As a second limitation, there are no follow-up measures were recorded, due to the associated inherent difficulties, for example, feel overwhelmed or disinterest in the request to answer the questionnaires for the third time. The difficulty to obtain follow-up measures is more frequently in situations where there is no control over the participants (e.g., they are not students). In this case, those who answered the questionnaires did not receive the intervention and the responses were anonymous. It should be mention that, the available evidence points to a reduction in the effect on follow-up measures, as a result of adaptation (e.g., Page \& Vella-Brodrick, 2013).

It is important to highlight that this study had the advantage of having been carried out entirely in a real organization, under a real problematic situation. Therefore, this program could be considered as a tool for the practitioners that could help to increase the probabilities of success under real problematic situations. This is relevant if it is considered that the organizations invest part of their budget in training their workers, and that, in response to this, they could demand demonstrable results (Veloso-Besio et al., 2018). 
Finally, the provisional evidence about the effect of interventions based on PP (and social skills) makes them an alternative, complementary to the traditional approach, which should be taken into account given the complex environment that organizations are facing. This scenario undoubtedly affects the well-being of workers who are at the base of the hierarchy (Mills et al., 2013), and to those who are in charge of them, that is, the immediate supervisors. 


\section{Referencias}

Aguirre, D. (2018). Trabajadores que practican la gratitud tienen un $66 \%$ menos de intenciones de renunciar [Workers who practice gratitude have $66 \%$ less turnover intentions]. El Mercurio online. Retrieved from: http://www.economiaynegocios.cl/ noticias/noticias.asp?id=499512

Avey, J. B., Avolio, B. J., \& Luthans, F. (2011a). Experimentally analyzing the impact of leader positivity on follower positivity and performance. The Leadership Quarterly, 22(2), 282-294.

Avey, J. B., Reichard, R. J., Luthans, F., \& Mhatre, K. H. (2011b). Meta-analysis of the impact of positive psychological capital on employee attitudes, behaviors, and performance. Human Resource Development Quarterly, 22(2), 127-152.

Avolio, B. J., Reichard, R. J., Hannah, S. T., Walumbwa, F. O., \& Chan, A. (2009). A meta-analytic review of leadership impact research: Experimental and quasi-experimental studies. The Leadership Quarterly, 20(5), 764-784.

Bakker, A. B., Rodríguez-Muñoz, A., \& Derks, D. (2012). La emergencia de la psicología de la salud ocupacional positiva [The emergence of positive occupational health psychology]. Psicothema, 24(1), 66-72.

Cameron, K., Mora, C., Leutscher, T., \& Calarco, M. (2011). Effects of positive practices on organizational effectiveness. Journal of Applied Behavioral Science, 47(3), 266-308.

Castro, M. C., Delgado, J. B., Ramírez, Á. B., Rovira, D. P., Ojeda, F. G., \& Salazar, D. A. (2012). Estructura factorial de la escala de satisfacción con la vida en una muestra de estudiantes universitarios chilenos [Factorial Structure of the Satisfaction with Life Scale in a Chilean University Sample]. Revista Mexicana de Psicología, 29(2), 157-164.

Cohen, J. (1988). Statistical power analysis for the behavioral sciences (2nd ed.). Hillsdale, NJ: Erlbaum.

Cuadra-Peralta, A. \& Veloso-Besio, C. (2007). Liderazgo, clima y satiadacción laboral en organizaciones [Leadership, climate and job satisfaction in organizations]. Revista Universum, 22(2), 40-56.

Cuadra-Peralta, A., Veloso-Besio, C., Iribaren, J., \& Pinto, R. (2017). Intervention for supervisors, based on social skills and leadership, in order to improve organizational climate perception and organizational performance outcomes. Journal of Organizational Change Management, 30(2), 281-292.

DeCoster, J. (2012). Converting effect sizes. Available in: http:// stat-help.com/spreadsheets.html

Diener, E., Emmons, R. A., Larsen, R. J., \& Griffin, S. (1985). The satisfaction with life scale. Journal of Personality Assessment, 49(1), 71-75.

Diener, E., Lucas, R. E., \& Oishi, S. (2005). Subjective well-being: The science of happiness and life satisfaction. In C. R. Snyder \& S. J. Lopez (Eds.), The Handbook of Positive Psychology (pp. 63-73). New York: Oxford University Press.

Diener, E. \& Oishi, S. (2005). The nonobvious social psychology of happiness. Psychological Inquiry, 16(4), 162-167.

Diener, E. \& Seligman, M. E. P. (2004). Beyond money: Toward an economy of well-being. Psychological Science in the Public Interest, 5(1), 1-31.

Erdogan, B., Bauer, T. N., Truxillo, D. M., \& Mansfield, L. R. (2012). Whistle while you work: A review of the life satisfaction literature. Journal of Management, 38(4), 1038-1083.
Ford, J. K., Baldwin, T. T., \& Prasad, J. (2018). Transfer of training: The known and the unknown. Annual Review of Organizational Psychology and Organizational Behavior, 5(1), 201-225.

Gardner, R. C. (2003). Estadística para Psicología Usando SPSS para WINDOWS. Pearson Education: México.

Gil, F. (1998). Habilidades Sociales en el Trabajo y en las Organizaciones [Social Skills at Work and in Organizations]. In F. Gil, \& J. Ma. León (Eds.), Habilidades Sociales: Teoría, Investigación e Intervención (pp. 186-200). Madrid: Síntesis.

Gil, F., Cantero, F. J., \& Antino, M. (2013). Tendencias actuales en el ámbito de las habilidades sociales [Current trends in the field of social skills]. Apuntes de Psicología, 31(1), 51-57.

Gil, F., Rodríguez, F., \& Alcover, C. Ma. (1998). Management competences training. International Journal of Social Psychology, 13(2), 189-193.

Grant, A. M., Curtayne, L., \& Burton, G. (2009). Executive coaching enhances goal attainment, resilience and workplace well-being: A randomised controlled study. The Journal of Positive Psychology, 4(5), 396-407.

Grant, A. M. \& Wall, T. D. (2009). The neglected science and art of quasi-experimentation: Why-to, when-to, and how-to advice for organizational researchers. Organizational Research Methods, 12(4), 653-686.

Judge, T. A. \& Piccolo, R. F. (2004). Transformational and transactional leadership: A meta-analytic test of their relative validity. Journal of Applied Psychology, 89(5), 755-768.

Kelly, J. A. (2013). Entrenamiento de las habilidades sociales [Social skills training] (8a ed.). Bilbao: Descleé De Brouwer.

Layous, K. \& Lyubomirsky, S. (2014). The how, why, what, when, and who of happiness: Mechanisms underlying the success of positive interventions. In J. Gruber, \& J. Moscowitz (Eds.), Positive emotion: Integrating the light sides and dark sides (pp. 473-495). New York: Oxford University Press.

Le Blanc, P. M., \& Oerlemans, W. G. M. (2016). Amplition in the workplace: building a sustainable workforce through individual positive psychological interventions. Papeles del Psicólogo/ Psychologist Papers, 37(3), 185-191.

Luthans, F. \& Youssef, C. M. (2007). Emerging positive organizational behavior. Journal of Management, 33(3), 321-349.

Luthans, F., Youssef, C. M., Sweetman, D. S., \& Harms, P. D. (2013). Meeting the leadership challenge of employee well-being through relationship PsyCap and health PsyCap. Journal of Leadership \& Organizational Studies, 20(1), 118-133.

Lyubomirsky, S., Dickerhoof, R., Boehm, J. K., \& Sheldon, K. M. (2011). Becoming happier takes both a will and a proper way: An experimental longitudinal intervention to boost well-being. Emotion, 11(2), 391-402.

Meyers, M. C. \& van Woerkom, M. (2017). Effects of a strengths intervention on general and work-related well-being: The mediating role of positive affect. Journal of Happiness Studies, 18(3), 671-689

Meyers, M. C., van Woerkom, M., \& Bakker, A. B. (2013). The added value of the positive: A literature review of positive psychology interventions in organizations. European Journal of Work and Organizational Psychology, 22(5), 618-632.

Mills, M. J., Fleck, C. R., \& Kozikowski, A. (2013). Positive psychology at work: A conceptual review, state-of-practice 
assessment, and a look ahead. The Journal of Positive Psychology, $8(2), 153-164$

Moreno-Jiménez, B., Blanco-Donoso, L. M., Aguirre-Camacho, A., de Rivas, S., \& Herrero, M. (2014). Habilidades sociales para las nuevas organizaciones [Social skills for new organizations]. Behavioral Psychology/Psicología Conductual, 22(3), 585-602.

Morris, S. B. (2008). Estimating effect sizes from pretest-posttest-control group designs. Organizational Research Methods, 11(2), 364-386.

Mumford, T. V., Campion, M. A., \& Morgeson, F. P. (2007). The leadership skills strataplex: Leadership styles requirement across organizational levels. The Leadership Quarterly, 18(2), 154-166.

Page, K. M. \& Vella-Brodrick, D. A. (2013). The working for wellness program: RCT of an employee well-being intervention. Journal of Happiness Studies, 14(3), 1007-1031.

Park, N. \& Peterson, C. (2009). Achieving and sustaining a good life. Perspectives on Psychological Science, 4(4), 422-428.

Park, N., Peterson, C., \& Sun, J. K. (2013). La psicología positiva: Investigación y aplicaciones [Positive Psychology: Research and practice]. Terapia Psicológica, 31(1), 11-19.

Payne, H. (2005). Reconceptualizing social skills in organizations: Exploring the relationship between communication competence, job performance and supervisory roles. Journal of Leadership and Organizational Studies, 11(2), 63-77.

Peterson, S. J, Balthazard, P. A., Waldman, D. A., \& Thatcher, R. W. (2008). Neuroscientific implications of psychological capital: Are the brains of optimistic, hopful, confident, and resilient leaders different? Organizational Dynamics, 37(4), 342-353.

Quinlan, D., Swain, N., \& Vella-Brodrick, D. A. (2012). Character strengths interventions: Building on what we know for improved outcomes. Journal of Happiness Studies, 13(6), 1145-1163.

Riggio, R. E. \& Reichard, R. (2008). The emotional and social intelligences of effective leadership: An emotional and social skill approach. Journal of Managerial Psychology, 23(2), 169-185.

Robbins, S. P. \& Judge, T. (2017). Organizational behavior (17th ed.). Boston: Pearson.

Roche, M., Luthans, F., \& Haar, J. M. (2014). The role of mindfulness and psychological capital on the well-being of leaders. Journal of Occupational Health Psychology, 19(4), 476-489.

Salanova, M., Llorens, S., Acosta, H., \& Torrente, P. (2013). Positive interventions in positive organizations. Terapia Psicológica, 31(1), 101-113.

Salanova, M., Llorens, S., \& Martínez, I. M. (2016). Contributions from positive organizational psychology to develop healthy and resilient organizations. Papeles del Psicólogo/Psychologist Papers, 37(3), 177-184.

Salas, E. \& Cannon-Bowers, J. A. (2001). The science of training: A decade of progress. Annual Review of Psychology, 52(1), 471-499.

Salas, E., Tannenbaum, S. I., Kraiger, K., \& Smith-Jentsch, K. A. (2012). The science of training and development in organizations: What matters in practice. Psychological Science in the Public Interest, 13(2), 74-101.

Segrin, C. \& Taylor, M. (2007). Positive interpersonal relationships mediate the association between social skills and psychological well-being. Personality and Individual Differences, 43(4), 637-646.

Seligman, M. E. P. \& Csikszentmihalyi, M. (2000). Positive psychology: An introduction. American Psychologist, 55(1), 5-14.

Sin, N. L. \& Lyubomirsky, S. (2009). Enhancing well-being and alleviating depressive symptoms with positive psychology interventions: A practice-friendly meta-analysis. Journal of Clinical Psychology, 65(5), 467-487.

Stone, B. M. \& Parks, A. C. (2018). Cultivating subjective well-being through positive psychological interventions. In E. Diener, S. Oishi, \& L. Tay (Eds.), Handbook of Well-being (pp. 730-740). Salt Lake City, UT: DEF Publishers.

Veloso-Besio, C., Gil-Rodríguez, F., González-Acuña, D., Cuadra-Peralta, A., \& Valenzuela-Carrera, V. (2018). Evaluación de modalidades de intervención para mejorar satisfacción vital, satisfacción laboral y clima organizacional. [Evaluation of modality of intervention to improve life satisfaction, job satisfaction and organizational climate]. Interciencia, 43(5), 336-342.

Vera-Villarroel, P., Urzúa, A., Pavez, P., Celis-Atenas, K., \& Silva, J. (2012). Evaluation of subjective well-being: Analysis of the Satisfaction With Life Scale in Chilean population. Universitas Psychologica, 11(3), 719-728.

Warr, P., Cook, J., \& Wall, T. (1979). Scales for measurement of some work attitudes and aspects of psychological well-being. Journal of Occupational Psychology, 52(2), 129-148.

Warr, P. \& Nielsen, K. (2018). Wellbeing and work performance. In E. Diener, S. Oishi, \& L. Tay (Eds.), Handbook of Well-being (pp. 647-667). Salt Lake City, UT: DEF Publishers.

Waterman, A. S. (2013). The humanistic psychology-positive psychology divide: contrasts in philosophical foundations. The American Psychologist, 68(3), 124-133.

Zander, R. S., \& Zander, B. (2002). The art of possibility. New York: Penguin. 